\title{
Cladoceran abundance in relation to water quality parameters of Chakki Talab, Bodhan, Telangana
}

\author{
Vasudha Lingampally*, V.R.Solanki, D.L.Anuradha and Sabita Raja \\ Department of Zoology, Nizam College, Osmania University, Hyderabad, India \\ Received 01 Nov 2017, Accepted 31 Dec 2017, Available online 02 Jan 2018, Vol.8, No.1 (Jan/Feb 2018)
}

\begin{abstract}
In the present study an attempt has been made to evaluate water quality and related density of Cladocerans for a period of one year, October 2015 to September 2016. Water quality parameters such as temperature, $P^{H}$, total dissolved solids, dissolved oxygen, biological oxygen demand, total alkalinity, total hardness, chlorides, phosphates, and nitrates are presented here to relate with the abundance of Cladocerans. The Cladoceran abundance reflects the eutrophic nature of the Chakki talab.
\end{abstract}

Key words: Zooplankton, Cladocera, Water quality,Chakki talab, Eutrophication, Bodhan

\section{Introduction}

Zooplanktons are one of the most important biotic components influencing all the functional aspects of an aquatic ecosystem, such as food chains, food webs, energy flow and cycling of matter (Supritam pal et al.,2015).The zooplankton inhabiting freshwater responds quickly to environmental changes and hence their species indices fluctuate (Avinash 2014). One of the most important zooplankton components in freshwater lake environment are Cladocera. Cladocera is an order of small crustaceans commonly called water fleas. They occupy a key position in the aquatic food chain as the intermediate link between primary and secondary productivity and they also serve as model species in environmental toxicology because of their high sensitivity to water quality (Siciliano et al., 2015)

Cladocerans are important biological indicators for a wide range of environmental variables (Rumes et al., 2011). Cladocera show a strong response to environmental factors, such as trophic state, total phosphorus concentration, water depth, temperature, etc. Cladocera species are especially responsive to changes in $\mathrm{pH}$, reflecting their sensitivity to acidification (Edyta Zawisza et al., 2016).Therefore the present investigation was done to determine the monthly variations of cladocerans in relation to the water quality parameters of Chakki talab, Bodhan to know its current status.

\section{Materials and methods}

Bodhan town is spread $21.36 \mathrm{~km}^{2}$. The town Bodhan is located at latitude $18^{0} 39^{\prime} 36^{\prime \prime} \mathrm{N}$ and longitude $77^{0} 52^{\prime}$

*Corresponding author's ORCID ID: 0000-0003-1223-7059 DOI: https://doi.org/10.14741/ijcet.v8i01.10877
47" E. The Chakkitalab is a lake located on the south side of Bodhan town near residential localities. Sampling and physicochemical investigation was carried out according to standard methods, APHA (1989). Zooplankton samples were obtained by passing $50 \mathrm{~L}$ water through plankton net in each depth. Zooplankton samples were preserved in $4 \%$ formalin. Identification of Cladocerans was done with the help of fresh water biology Edmondson (1965). Counting of Cladocerans was done using Sedgwick- Rafter counter and the dilution technique. The population density of Cladocerans is represented per liter of water.

\section{Results and discussion}

The Cladocera were represented by two genera, Daphnia and Ceriodaphnia.These Cladocerans were found throughout the investigation period. Cladoceran density was maximum during February 2016 and minimum during the month of July 2016 (Graph 1). The density of Ceriodaphnia was more compared to Daphnia throughout the study period.

The surface water temperature of Chakki talab ranged from $21^{\circ} \mathrm{C}$ to $35^{\circ} \mathrm{C}$. According to Patel (2013) temperature is the prime factor affecting the occurrence and abundance of Cladocerans. Cladocera exhibited negative correlation with temperature (Graph 2A). Density of Cladocera was abundant during winter months. Maximum population of Cladocerans in winter could be attributed to favorable temperature and availability of food. Our findings were in confirmity with Harish kumar and Kiran (2016). But maximum density of Cladocera was reported in summer in Thigra reservoir by Dushyantkumar Sharma (2012). 
The $\mathrm{P}^{\mathrm{H}}$ ranged between7.8 to 8.6. Minimum $\mathrm{P}^{\mathrm{H}}$ was observed in the month of July while the maximum in April, 2016. Cladocerans exhibited slight positive correlation with $\mathrm{PH}^{\mathrm{H}}$ (Graph 2B). Cladocerans exhibited positive correlation with $\mathrm{PH}^{\mathrm{H}}$ in Varuna lake (Deepthi and Sadanand, 2014). Total dissolved solids ranged between 326 to $423 \mathrm{mg} / \mathrm{l}$. The Cladocera exhibited positive correlation with T.D.S. (Graph 2C).

Dissolved oxygen ranged between 4.1 to $6.8 \mathrm{mg} / \mathrm{l}$. The Cladocera showed negative correlation with DO (Graph 2D).Similar observation was noticed in Lake Vela (Antunes et al., 2003) Biological oxygen demand ranged between 24.3 to $42.4 \mathrm{mg} / \mathrm{l}$. The Cladocerans showed Positive correlation with B.O.D. (Graph 2E).

Chlorides ranged between 141.8 to $198.5 \mathrm{mg} / \mathrm{l}$. The Cladocerans exhibited positive correlation (Graph 2F). Similar findings were observed in Pandu lake, Bodhan (Solanki et al., 2016).Total alkalinity ranged between 138 to $183 \mathrm{mg} / \mathrm{l}$. Cladoceran exhibited positive correlation with total alkalinity (Graph 2G). Similar result was observed in Madappa lake (Deepthi and Sadanand, 2014). Total hardness ranged between 90 to $184 \mathrm{mg} / \mathrm{l}$. Cladocera showed negative correlation with total hardness (Graph 2H). Our results are in conformity with the findings of Tidame and Shinde (2012).

Nitrates ranged between 1.44 to $1.7 \mathrm{mg} / \mathrm{l}$. The Cladoceran abundance was high when nitrate content was more (Graph 2I). Cladocerans are reported to be the indicators of eutrophic nature of water bodies (Sharma, 2001; Tapas Kumar and Bidhan, 2013). Phosphates ranged between 0.036 to $0.087 \mathrm{mg} / \mathrm{l}$. The Cladocerans showed positive correlation with phosphates (Graph 2J). Rao (1987) stated that Cladocerans are rich in eutrophic waters. Shah and Pandit (2013) found an increase in Cladoceran density with the increase in the nutrient content of the water in Wular Lake, Kashmir.

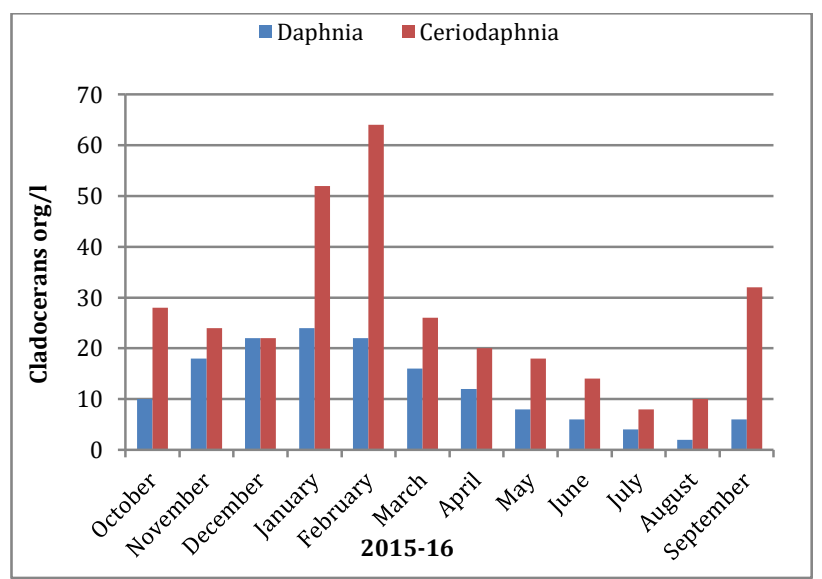

Graph 1 Monthly variations of Cladocerans org/l of Chakki talab

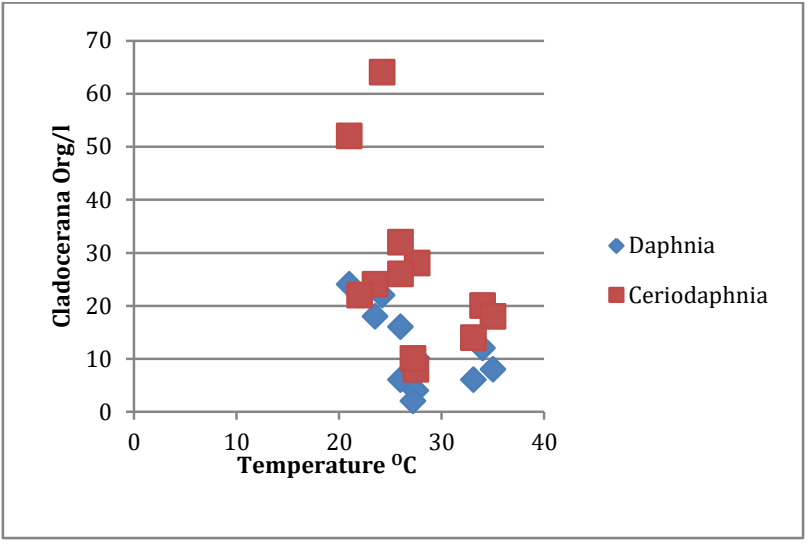

(A)

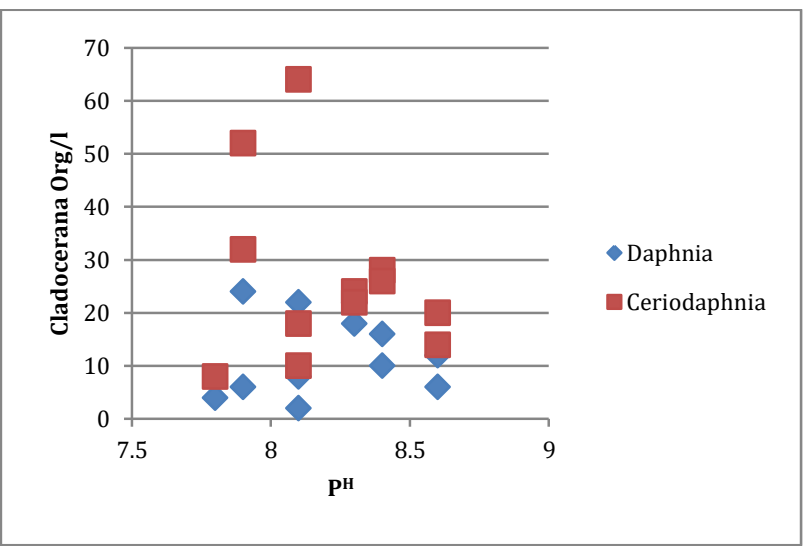

(B)

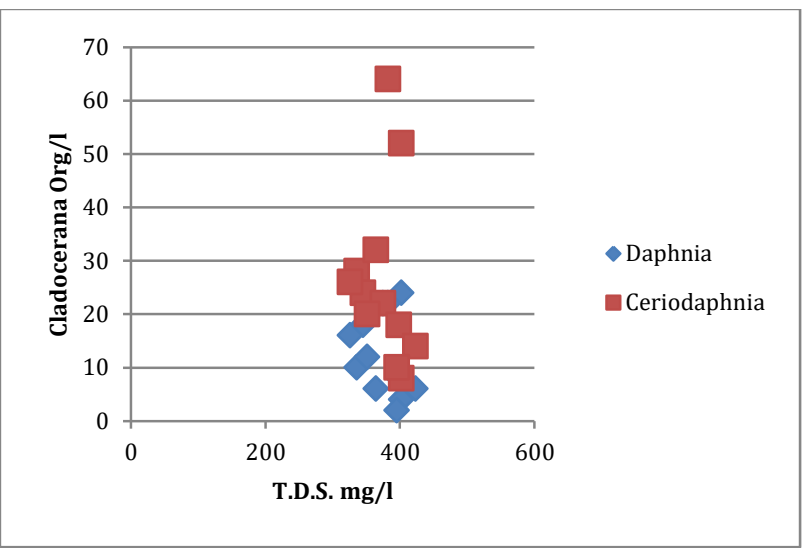

(C)

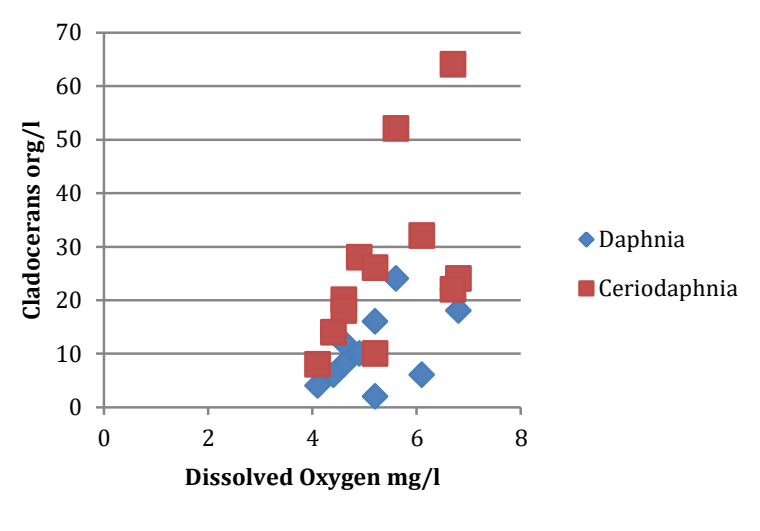

(D) 


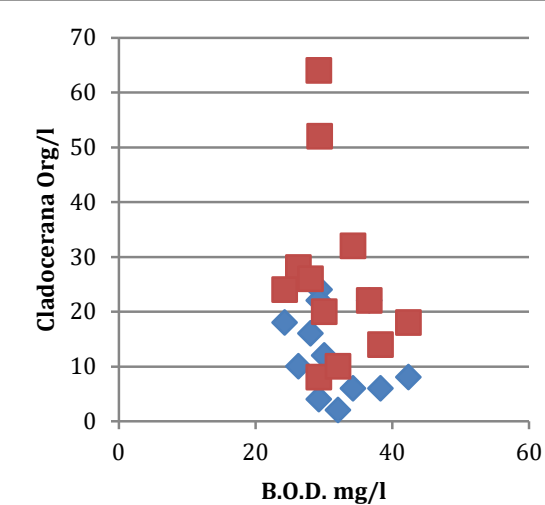

$\bullet$ Daphnia

Ceriodaphnia

(E)

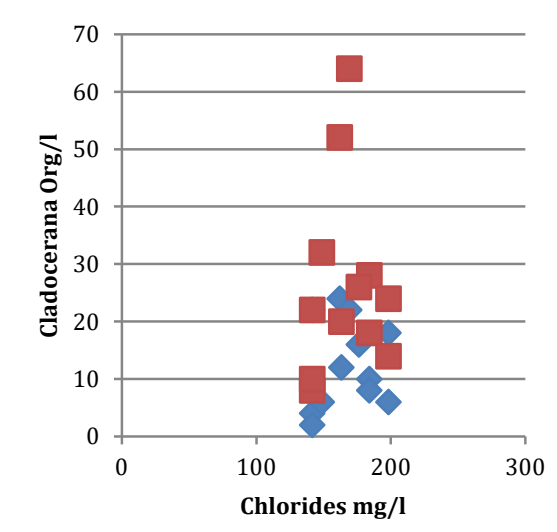

$\bullet$ Daphnia

Ceriodaphnia

$(\mathrm{F})$

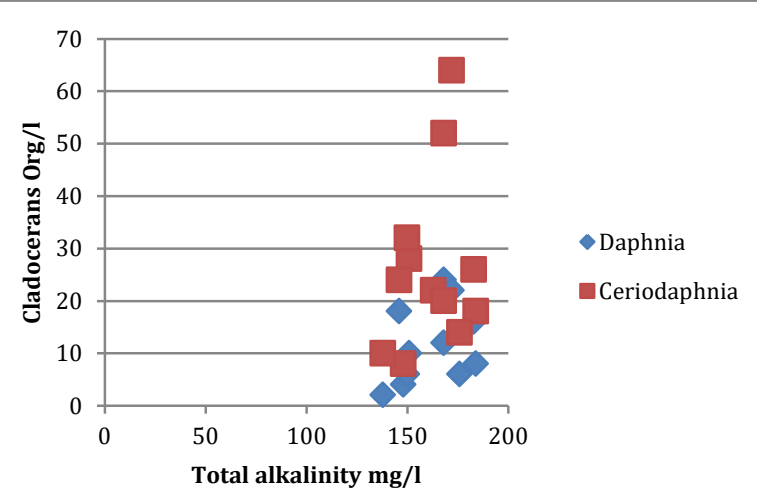

(G)

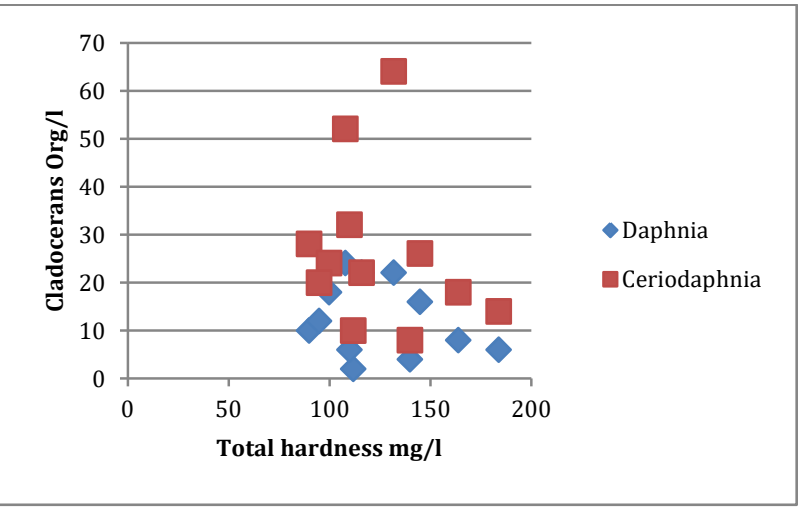

(H)

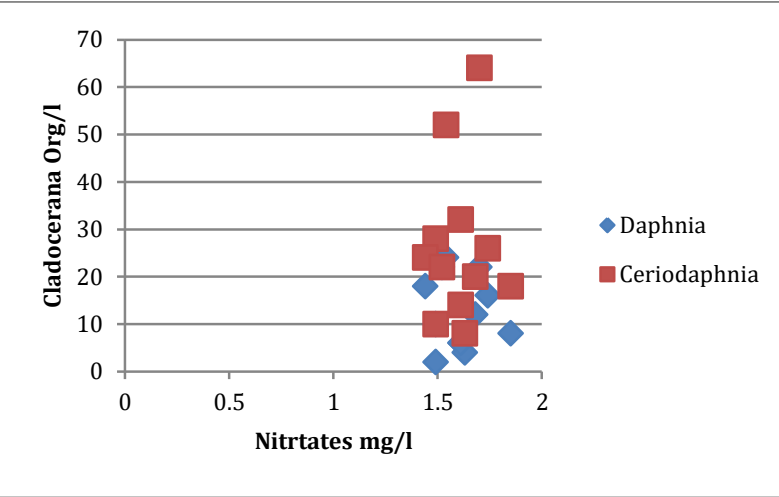

(I)

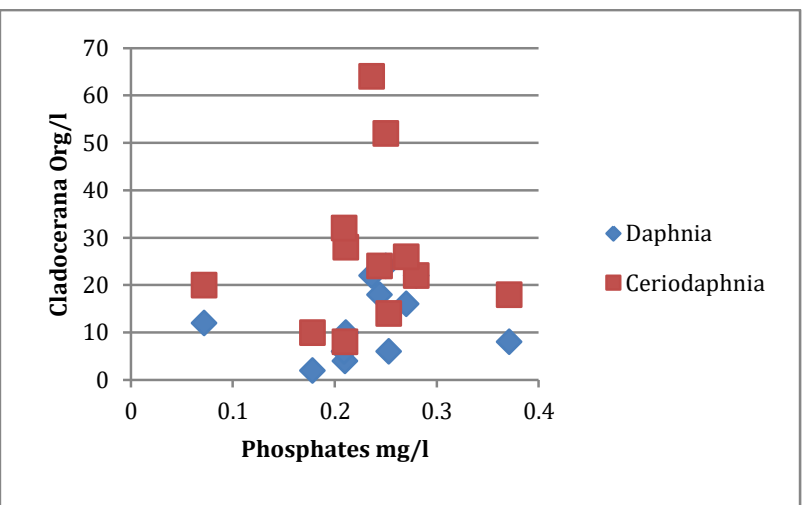

(J)

Graph 2(A-J) Correlation between Cladocera and water quality parameters

\section{Conclusion}

In the present study monthly variation of Cladoceran abundance was observed. They showed direct or indirect relationship with the water quality parameters studied. The Cladoceran abundance reflects the eutrophic nature of the Chakki talab.

\section{References}

American Public Health Association (APHA)1989. Standard Methods for the Examination of Water and Wastewater, 17th edn. American Public Health Association, Washington DC.

Avinash B. Gholap (2014). Species diversity indices of zooplankton from Sadatpur reservoir, Ahmednagar, Maharashtra. Annals of Biological Research, Vol.5, No.4, pp. 58-61.

Deepthi S. and Sadanand M. Yamakanamardi(2014) Abundance Of Cladoceran Zooplankton In Varuna, Madappa And Giribettethe Lakes Of Mysore, Karnataka State, India. International Journal of Science, Environment and Technology, Vol. 3, No.3, pp. $885-900$.

Dushyant kumar Sharma and R.P Singh (2012), seasonal variation in zooplankton diversity in Tighra Reservoir Gwalior (M.P.) Indian Journal of Science and Research, Vol.3, No.2, pp.155-161.

Edmondson W.T. (Ed), (1965). Fresh Water Biology. John Wiley and Sons inc., New York.

Edyta Zawisza, Izabela Zawiska, Alexander Correa-Metrio (2016) Cladocera Community Composition as a Function of Physicochemical and Morphological Parameters of 
Dystrophic Lakes in NE Poland, Wetlands, Vol. 36, pp.1131-1142.

K Harish Kumar and BR Kiran (2016) A report on diversity of cladocera in sewage fed tank of Bhadravathi taluk, Karnataka. International Journal of Fauna and Biological Studies, Vol.3, No.2, pp. 18-20.

Rao NG. Synecology of the lake Rangsagar in relation toLimnology and eutrophication, Ph. D. Thesis, M L.Sukhadia University, Udaipur (Rajasthan) India, 1987.

Rumes B, Eggermont H, Verschuren D (2011) Distribution and faunal richness of cladocera in western Uganda crater lakes. Hydrobiologia, Vol.676, pp.39-56. doi:10.1007/s10750-011-0829-7.

S.C. Antunes, N. Abrantes, F. Gonçalves (2003) Seasonal variation of the abiotic parameters and the Cladoceran assemblage of Lake Vela: comparison with previous studies. Annales de Limnologie - International Journal of Limnology,Vol.39, No.3, pp.255-264.

Shah J.A. and Ashok K. Pandit, (2013). Diversity and Abundance of Cladoceran Zooplankton in Wular Lake, Kashmir Himalaya. Research Journal of Environmental and Earth Sciences. Vol.5, No.7,pp. 410-417.

Sharma BK(2001) Biological monitoring of freshwaters with reference to role of freshwater Rotifera as biomonitors. In: Water Quality Assessment Biomonitoring and Zooplanktonic Diversity (B.K. Sharma).Ministry of Environment and Forests, Government of India, New Delhi, pp. 83-97.
Siciliano A, Gesuele R, Pagano G, Guida M (2015). How Daphnia (Cladocera) Assays may be used as Bioindicators of Health Effects? Journal of Biodiversity \& Endangered Species,S1: S1.005. doi:10.4172/2332-2543.S1-005.

Supratim Pal, Debashis Das and Kaushik Chakraborty (2015) comparative study on physico-chemical characteristics and Zooplankton diversities between natural and man-made Wetlands at Cooch Behar, West Bengal, India. European Journal of Experimental Biology, Vol.5, No.5, pp.85-97.

Tapas Kumar Dutta, Bidhan Patra C(2013) Biodiversity and seasonal abundance of Zooplankton and its relation to physico-chemical parameters of Jamunabundh, Bishnupur, India. International Journal of Scientific and Research Publications, Vol.3, No.8, pp. 1-7.

Tidame S.K and Shinde S. S (2012) Report on correlation of zooplankton with physico- chemical factors from freshwater temple pond. Journal of Experimental Sciences, Vol.3, No. 7 pp. 13-16.

V.R. Solanki , Vasudha Lingampally, Vidya Jayaram and S. Sabita Raja (2016). Chlorides impact on zooplankton of Pandu lake, Bodhan, Telangana, Ecology, Environment and Conservation. Vol. 22, No.2, pp.809-812. 